\title{
Strategies-Based ESP Instruction (SBI) of Reading Comprehension: Male vs. Female Students
}

\author{
Seyyed Hossein Kashef*, Ayoob Damavand ${ }^{1 *} \&$ Azizollah Viyani $^{2} *$
}

*Correspondence: School of Languages, Literacies and Translation, Universiti Sains Malaysia Sungai Dua, 11800, Pulau Penang, Malaysia Tel: 60-105-099-220Ｅ-mail: mhkashef@gmail.com

${ }^{1}$ *School of Educational Studies, Universiti Sains Malaysia Sungai Dua, 11800, Pulau Penang, Malaysia E-mail: adamavand@gmail.com

${ }^{2}$ *School of Educational Studies, Universiti Sains Malaysia, Penang, Malaysia Sungai Dua, 11800, Pulau Penang, Malaysia E-mail:viyaniaziz@gmail.com

Received: April 15, 2012 Accepted: June 3, 2012 Published: June 16, 2012 doi:10.5296/ije.v4i2.1625 URL: http://dx.doi.org/10.5296/ije.v4i2.1625 


\begin{abstract}
The present study aimed at exploring the effect of a Strategies-Based Instruction (SBI) on improving male and female students' reading comprehension ability in an ESP context. The main assumption was that SBI would be more successful in developing reading comprehension of females compared to male students through using effective strategies and skills delivered in SBI method. The participants, within the age range of 18-22, included 24 male and 26 female students who were an intact experimental group. Following a pretest, treatment (15 weeks, 2 sessions per week), and a posttest, the obtained data was analyzed using ANOVA to examine the effects of the independent variables, namely, method of instruction and gender. The results of the analysis showed that although the teaching intervention had a significant effect on students' reading comprehension, gender's effect was not significant. The findings are discussed in relation to effective reading comprehension instruction through the use of cognitive and metacognitive strategies in ESP teaching contexts.
\end{abstract}

Keywords: strategies-based instruction (SBI), ESP, gender, reading comprehension 


\section{Introduction}

In many EFL contexts of Asian countries, English is a required subject of students in all levels of their educational life. The main goal of instructing English in these contexts is to help students succeed in their examinations and enter higher levels of education (Huang, 2006). Although reading comprehension is an essential part of these exams, students usually do not receive any instruction on reading skills and strategies necessary to read some complicated texts in their educational life. Then, they enter university and study specific English related to their own fields of study and except English majors, they do not have to take English courses after the first year of their studies (Huang, 2006). The problem starts when the students have to struggle with some technical lengthy texts during their university life. This may be, partly due to the fact that ESP instructors do not provide their students with different skills and strategies required to succeed in their reading comprehension goals. During such classes, as Huang (2006) mentions, some more proficient students will acquire some necessary reading skills by themselves, while other less proficient ones will lose their confidence and interest in the course and as a result they will refer to the translation versions of their texts in order to pass the exams. It seems that these classes will not train the students with satisfactory reading abilities.

The problem emerges when students enter universities and their curricula focus on the content area of their specialization. Since, except English majors, most students do not have to take English courses after the first year of their studies, they begin to struggle with difficulties posed by complex English texts college professors assign them to read.

Therefore, it could be said that an ESP course which concentrates on three main factors of meeting specific needs of the learners, making use of the underlying methodologies of the discipline it serves, as well as focusing on the appropriate skills necessary for this purpose will help the learners to succeed in their goals. In other words, a successful ESP course will be a course that takes into consideration three main factors of learners' needs, a suitable methodology, and the essential language skills needed by the learners to accomplish their objectives.

However, in some Asian countries including Iran, English is commonly taught through the unfashionable Grammar-Translation Method (GTM) (Pritchard and Nasr 2004; Iranmehr, et al., 2011). Contrary to Fiorito's definition of ESP program, what exists in the literature indicates that in GTM students have to learn language grammar and vocabulary so that they can be able to translate the readings and do the exercises (Chastain, 1988). Among the shortcomings of GTM, its lack of concern with cognitive principles (Chastain, 1988) leads to the inability of students to develop some necessary skills and strategies required in reading comprehension. This might be the worst pitfall that decreases its efficiency which, according to Fuertes-Olivera and Gomez-Martinez (2004) leads to some passive learners who do not participate in class activities. Therefore, in this context, SBI method makes use of a number of appropriate features of a variety of teaching methods to develop learners' reading comprehension ability seems to contribute positively to learning outcomes.

In this vein, Flowerdew and Peacock (2001) pointed out some necessary macro- and 
micro-skills of reading that are needed by English for Academic Purposes (EAP) students. Making use of the learners' existing knowledge to understand new material and matching new knowledge with their schema are macro-skills; and recognizing logical relationships, definitions, generalizations, examples, explanations and predictions, and distinguishing fact from opinion are some crucial micro-skills. Similarly, Hauptman (2000) also noticed that learners with well-provided background knowledge but low language proficiency could get the main ideas of texts.

Some studies have revealed that different reading strategies are used for different types of texts focusing on differential nature of reading strategies used by poor and good readers and male and female students, as well. For example, according to Golinkoff (1975), one of the major characteristics of poor readers is that they have the same way of reading for all kinds of texts. In a definition by Pearson and Fielding (1991, p. 847), they have explained strategies as "conscious and flexible plans that readers apply to particular texts and tasks." According to such a definition and also the concept that language learning and reading are skills and therefore "teachable" through training, many studies have focused on teaching strategies explicitly to improve the students' reading comprehension. Meta-cognitive strategies have also been emphasized as useful strategies for effective reading. As mentioned by Carrell (1998), successful use of a reading strategy depends on meta-cognitive application of such strategy. In other words, successful readers are both aware and flexible in the use of different reading strategies needed to accomplish a task. Occasionally, the findings of these studies also showed that females outperformed males in some cases.

Fuertes-Olivera and Gomez-Martinez (2004) conducted a relevant study in Spanish ESP context. They tried to analyze some learning factors affecting Spanish students of business English. By performing different correlation and regression analyses of factors such as Reading, Attendance, thinking in L1, and GTM, the researchers found that the more students thought in L1 (an outstanding feature of GTM), and the more they had been taught through the GTM, the more errors they made. Results also indicated positive influence reading has on L2 learning: "The more you read in the L2, the more you leave your L1 aside, as reading is not a translation exercise, but an exercise of processing meaning"(p. 11).

Dhieb-Henia (2003) carried out a study on 62 Tunisian students to investigate how meta-cognitive strategy training influenced undergraduate biology students' declarative and procedural knowledge, and also to examine their choice and use of strategies while reading research articles. In this study, two groups of biology students took pre- and post-course reading tests. The results of tests and protocols revealed "the effectiveness of meta-cognitive strategy training in improving the subjects' familiarity with and proficiency in reading research articles"(Dhieb-Henia, 2003, p. 387). Thus, the role of teaching meta-cognitive strategies is emphasized as being eminent in developing the students' reading comprehension EFL contexts.

Regarding the use of metacognitive strategies among Iranian EFL learners in reading comprehension, a recent study was carried out by Bahmani (2009). She compared the use of metacognitive strategies between high proficient learners and their low proficient peers in her 
study. The participants formed 100 students in two distinct levels of pre-intermediate versus high-intermediate in a public language Institute (Jahad Daneshgahi). She utilized four instruments, namely metacognitive strategy use, motivation questionnaire, First Certificate in English Test reading paper, and Preliminary English Test reading paper for data collection. After the data analysis through independent t-tests, the results revealed a significance difference between the two groups in terms of metacognitive strategy use favoring high proficient learners.

Actually, this study is in an action research format developed by the teacher himself during the instruction period to examine if there is any significant difference between males and females in their reading comprehension. Action research is a kind of survey carried out by instructors which is more directed to teacher and learner improvement than it is to theory building, though it can be applied for theory building, as well (Mackey \& Gass, 2005).

\section{Method}

The study is of a pretest, posttest intact group design that investigates the effect of a Strategies-Based Instruction on reading comprehension development of male and female students in a class.

\subsection{Participants}

The initial sample of this study consisted of 70 freshmen management students of Urmia University in different subfields. By means of a three part questionnaire and a pretest, 50 homogeneous subjects were chosen in terms of their age range, reading comprehension ability, and motivational features for the purpose of this study. The selected subjects were at the same level in terms of reading comprehension ability according to their obtained scores in the pretest. They consisted of 24 males and 26 females.

\subsection{Instruments}

1. A questionnaire: The questionnaire was used to select a homogeneous group of students and also to control some intervening variables like motivation and age. It included some questions about the subjects' demographic information, English language experience, and motivation. The first part of the questionnaire elicited some main information about subjects including age range, and gender. In fact, to control the moderating effect of age, the subjects within the age range of 18 to 22 were selected for the purpose of this study. The second section elicited data on subjects' assessment of their English as well as their exposure to it. Data from this section lead to the exclusion of subjects who reported longer exposures to EFL or having stayed in English speaking countries for more than one year. Another section of the questionnaire examined learners' motivation towards English language learning. In order to have homogeneous groups in terms of motivation and to eliminate the mediating role of this important factor as much as possible, a modified version of Gardener's (1985) motivation questionnaire was used. This section contained 11 statements indicating integrative and instrumental motivation for EFL learning. It was assessed via a serious of Likert-format items that had five scales, including strongly agree, agree, neutral, disagree, and strongly disagree. Participants who were identified as not motivated integratively or 
instrumentally were excluded from the study.

2. General and Technical Reading Tests: Two standard and reliable tests of English reading comprehension, one as a pretest and the other one as a posttest were adopted. Both tests were divided into 2 parts, namely, general and specific English.

The general English section included 3 reading passage followed by 5 multiple-choice items. The specific section contained 2 reading passages (relevant to management students), each followed by 5 multiple-choice items. Both tests were piloted on 35 students and their reliability was calculated using the KR-21 formula. The reliability of the tests was within an acceptable range (pretest: 0.71 and posttest: 0.75 ).

\subsection{Procedure}

The study was conducted at Management Faculty of Urmia University. The participants formed a reading class that was held two sessions (approximately 90 minutes) a week. The class was an intact group taught by the researcher himself through SBI method. All the data was collected during 4 months. In the beginning, the questionnaire along with the pretest was administered to the learners in order to establish the initial ability of subjects and commence treatment. Then, after choosing homogeneous students (in terms of age range, language proficiency, and motivation), the experiment was started.

As already mentioned, the purpose of the study was to examine how a method of SBI which teaches students reading strategies and skills can improve reading comprehension ability of different genders. Therefore, cognitive and metacognitive strategies were introduced and taught to the students. An explanation of the teaching procedures in this class is presented in the following.

The teacher devoted the first three sessions of the class to introducing and teaching the reading strategies. Then, he tried to point out the important role of these strategies and skills in dealing with different types of English texts. Finally, he modeled a bunch of cognitive and metacognitive strategies and skills and prepared the students to utilize them. In the next sessions, the teacher followed a fixed pattern. He opened the lesson by asking the students some questions to engage them in the topic and activate their background knowledge. The students had to pre-study the lesson that was going to be taught each session. Then, the teacher asked the students to read 'the words in context' part which encompassed the sentences in which the new words of each unit were used. Afterward, the teacher made the students read the passage and students implement different cognitive and metacognitive strategies while reading in order to understand the passages and answer the questions. The students were explained that the purpose of reading a text might differ in different tasks. Sometimes, a general understanding is required in order to answer the questions after a reading. For this purpose, skimming would be a good technique. However, some questions focus on specific information included in a text for which scanning technique would be more appropriate.

Randomly, the teacher asked one of the students to read one paragraph of the text, and had the other students summarize that paragraph. Sometimes, he asked the students to give 
the main idea of the text in one paragraph. The students were encouraged to guess the meaning of unknown words or ignore them if not possible. The teacher trained the students to use various appropriate techniques (e.g. guessing meaning, using clues, inferencing, summarizing, taking notes, etc.) whenever necessary. Thus, the students were aware of which technique to use in order to answer a specific kind of question. Therefore, the class in which the SBI method was taught was divided into two parts: first, teaching the students some cognitive and meta-cognitive strategies, and second, getting the students to use those strategies in the process of reading and answering the questions.

Then, after 15 weeks of instruction ( 2 sessions per week), the posttest was administered to the group. Consequently, the possible differences between the two genders in terms of their reading comprehension were analyzed. As it was mentioned before, the main objective was to find out if the SBI method had any effect on the development of learners' reading comprehension ability.

\section{Findings}

In order to analyze the obtained data, ANOVA was used to measure the possible effect of the method as well as gender on the development of the student's reading comprehension ability.

As stated before, a reading comprehension test was administered as a pretest to examine whether any initial differences existed between the genders before starting the treatment. The obtained results showed that the means of males $(M=75.5)$ and females $(M=74.1)$ were not significantly different to begin with.

Then, data from the posttest was analyzed to see the effect of treatment. To test the proposed assumptions, the author used ANOVA with the intact group taking method of instruction as independent variable, gender as the moderator and reading comprehension as the dependent one. The results of ANOVA revealed that the teaching intervention (SBI) had a significant effect $(\mathrm{F}=7.60, \mathrm{P} \leq .05)$ on students reading comprehension while there was no significant effect of gender on participants' reading comprehension ability (Table 1). This means that the instruction was quite successful in improving students reading comprehension although males and females gained similar ability in reading comprehension through SBI method.

As the comparison of the means across groups (Table 2) shows, there is not any remarkable difference between males $(\mathrm{M}=82.82)$ and females $(\mathrm{M}=82.92)$ in performing the tests. Table 2 shows the means and standard deviations across the groups as far as reading comprehension ability in the posttest is concerned. Figure 1 represents the interaction of genders. It shows that the means of the intact group for males and females are nearly the same. 
Table 1. The Results of ANOVA for Reading Comprehension

\begin{tabular}{c|c|c|c|c}
\hline Sources & Mean & df & F & Sig. \\
\hline SBI(treatment) & 29.48 & 1 & 7.60 & .007 \\
\hline Gender & 1.88 & 1 & 0.31 & .861 \\
\hline
\end{tabular}

$(\mathrm{P} \leq .05)$

Table 2. Descriptive Statistics for the Posttest Scores

\begin{tabular}{c|c|c|c}
\hline Gender & Mean & SD & N \\
\hline Male & 82.82 & & \\
\hline Female & 82.92 & 9.79 & 24 \\
\hline Total & 82.86 & 4.99 & 26 \\
\hline & & 8.29 & 50 \\
\hline
\end{tabular}

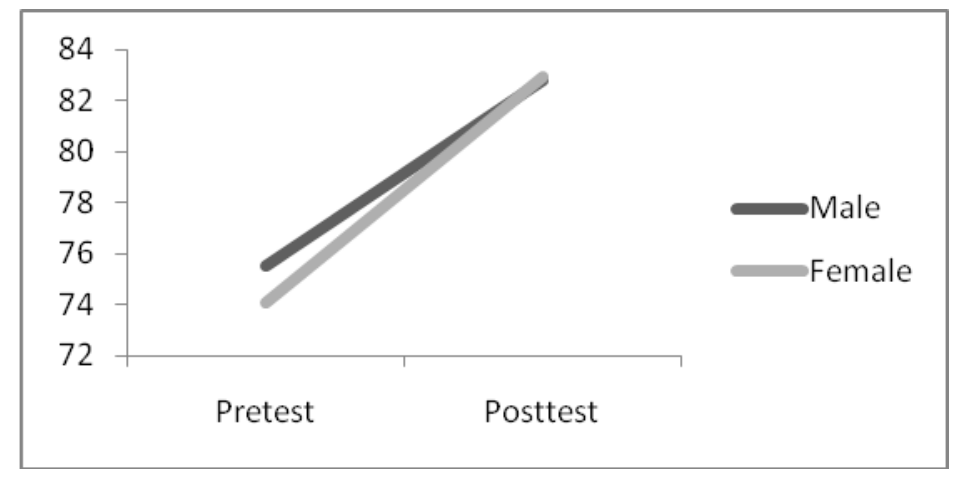

Figure 1. Means of Reading Comprehension across Genders

\section{Discussion and Conclusion}

This study confirmed several researches (e.g. Huang, 2006; Dhieb-Henia, 2003; Flowerdew and Peacock, 2001) proposing positive effects of cognitive and meta-cognitive skills and strategies training on improving reading comprehension ability of students.

The findings emphasize the efficacy of training university EFL students in a variety of reading strategies and skills to empower them with the flexibility required to operate under different constraints in dealing with different types of reading texts (Carrell, 1998).

As a result, this study supports the fact that teachers may have to devote sometime to be 
sure that their students correctly understand and accept the daily routines of a communicative methodology. On the other hand, it does not approve the studies confirming gender effect on reading comprehension. The current study highlights the crucial effect of a strategies-based instruction on developing subjects' reading comprehension ability; however, the findings call attention to some issues to be considered in further research. This study, in an action research format, mainly focused on an intact group and one method of instruction and its effects on developing reading comprehension ability of male and female management students; further research might investigate the possible effects some other methods of instruction might have on students with different levels of motivation and in different fields of study.

\section{References}

Bahmani, M. (2009). The use of meta-cognitive strategies among Iranian EFL learners with varying levels of proficiency in reading comprehension. Unpublished master's thesis, Urmia University, Urmia.

Carrell, P. L. (1998). Can reading strategies be successfully taught? The Language Teacher (online), 22/3, 55 paragraphs. $\quad$ Retrived from http://langue.hyper.chubu.ac.jp./jalt/pub/tlt/98/mar/carrell.html

Chastain, K., (1988). Developing second language skills, theory and practice. Harcourt Brace Jovanovich, Inc.

Dehieb-Henia, N. (2003). Evaluating the effectiveness of metacognitive strategy training for reading research articles in an ESP context. Journal of English for Specific Purposes, 22, 387-417. http://dx.doi.org/10.1016/S0889-4906(03)00017-6

Fiorito, L. (2005). How is English for specific purposes different from English as a second language, also known as general English. Teacher articles, using English.com

Flowerdew, L. (2005). Integrating traditional and critical approaches to syllabus design. Journal of English for academic purposes, 4, 135-147. http://dx.doi.org/10.1016/j.jeap.2004.09.001

Flowerdew, J., \& Peacock, M. (2001). Research Perspectives on English for Academic Purposes. Cambridge: Cambridge University Press.

Fuertes-Olivera, P. A., \& Gomez-Martinez, S. (2004). Empirical assessment of some learning factors affecting Spanish students of business English. Journal of English for Specific Purposes, 23, 163-180. http://dx.doi.org/10.1016/S0889-4906(02)00044-3

Golinkoff, R. M. (1975). A comparison of reading comprehension processes in good and poor comprehenders. Reading Research Quarterly, 11, 623-659. http://dx.doi.org/10.2307/747459

Hauptman, P.C. (2000). Some hypotheses on the nature of difficulty and ease in second language reading: an application of schema theory. Foreign Language Annals 33, 622-631. http://dx.doi.org/10.1111/j.1944-9720.2000.tb00931.x 
Hayati, A.M. (2008). Teaching English for Special Purposes in Iran: Problems and suggestions. Arts and Humanities in Higher Education, 7, 149-165. http://dx.doi.org/10.1177/1474022208088645

Huang, S.-C. (2006). Reading English for academic purposes -What situational factors may motivate learners to read? System, 34, 371-383. http://dx.doi.org/10.1016/j.system.2006.04.006

Hutchinson, T., \& Waters, A. (1987). English for Specific Purposes. Cambridge: Cambridge University Press. http://dx.doi.org/10.1017/CBO9780511733031

Iranmehr, A., Erfani, S. M., \& Davari, H. (2011). Integrating Task-based Instruction as an Alternative Approach in Teaching Reading Comprehension in English for Special Purposes: An Action Research. Theory and Practice in Language Studies, 1(2), 142-148. http://dx.doi.org/10.4304/tpls.1.2.142-148

Mackey, A., \& Gass, S.M. (2005). Second language research: methodology and design. Lawrence Erlbaum Associates, Inc., Publishers.

Pearson, P. D., \& Fielding, L. (1991). Comprehension instruction. In R. Barr, M. L. Kamil, P. Mosenthal, \& P. D. Pearson (Eds.), Handbook of reading research, Vol. II (pp. 815-860). New York: Longman.

Pritchard, R. M. O., \& Nasr, A. (2004). Improving reading performance among Egyptian engineering students: principles and practice. English for Specific Purposes, 23, 425-445. http://dx.doi.org/10.1016/j.esp.2004.01.002

\section{Copyright Disclaimer}

Copyright reserved by the author(s).

This article is an open-access article distributed under the terms and conditions of the Creative Commons Attribution license (http://creativecommons.org/licenses/by/3.0/). 